\title{
Fidesz, liberal democracy and the fundamental law in Hungary
}

\author{
Gabriel Gomez $\cdot$ Sven Leunig
}

Accepted: 28 October 2021 / Published online: 9 December 2021

(C) The Author(s) 2021

\begin{abstract}
After its landslide victories of 2010, 2014 and 2018, Fidesz has introduced numerous institutional changes in the Hungarian political system. The academic research has emphasized the illiberal and antidemocratic character of these reforms, and the populist ideology of the party has been widely considered as the underlying force behind them. This study analyzes the most important reform that Fidesz has undertaken: the new Fundamental Law, enacted in 2012. We examine whether this change can be regarded as a violation of liberal democratic principles, and, if that is the case, whether it can be linked to the populist character of Fidesz. We found that some of the most criticized dispositions of the newly enacted constitution cannot be regarded as violations of liberal democratic principles, whereas other changes clearly constitute attacks to the foundations of Hungarian democracy, mainly affecting the separation of powers and the civil rights of minorities, These findings are largely consistent with the effects of populist governments on democracy as documented in the literature.
\end{abstract}

Keywords Hungary · Fidesz $\cdot$ Liberal Democracy $\cdot$ Populism · Fundamental Law \footnotetext{
found in the text.

Gabriel Gomez · Sven Leunig $(\bowtie)$

Institut für Politikwissenschaft, Universität Jena, Jena, Germany

E-Mail: s.leunig@uni-jena.de

Gabriel Gomez

E-Mail: gabrieg98@zedat.fu-berlin.de
}

We are grateful to the following scholars, as well as the editors and the anonymous reviewer, for their useful feedback on a previous draft of this article: Giovanni de Ghantuz-Cubbe, Tom Mannewitz, Tim Niendorf and Torsten Oppelland. We are, of course, solely responsible for any mistakes to be 


\section{Fidesz, Liberale Demokratie und das Grundgesetz in Ungarn}

Zusammenfassung Nach ihren Erdrutschsiegen bei den Wahlen von 2010, 2014 und 2018 hat Fidesz zahlreiche institutionelle Veränderungen im ungarischen politischen System eingeleitet. Die akademische Forschung hat den illiberalen und antidemokratischen Charakter dieser Reformen betont, hinter denen die populistische Ideologie der Partei weithin als die zugrundeliegende Kraft angesehen wurde. Die vorliegende Studie analysiert die wichtigste Reform, die Fidesz durchgeführt hat: die Verabschiedung der neuen Verfassung (,Grundgesetz“) im Jahr 2012. Wir prüfen, ob die Änderungen der Verfassung im Vergleich zu ihrer Vorgängerin als Verstoß gegen liberale demokratische Grundsätze angesehen werden kann, und, wenn dies der Fall ist, ob eine Verbindung zwischen diesen neuen Bestimmungen und dem populistischen Charakter der Fidesz besteht. Wir stellten fest, dass einige der am meisten kritisierten Bestimmungen der neu verabschiedeten Verfassung nicht als Verstöße gegen liberale demokratische Prinzipien angesehen werden können, während andere Änderungen eindeutig Angriffe auf die Grundlagen der ungarischen Demokratie darstellen, die hauptsächlich die Gewaltenteilung und die Bürgerrechte von Minderheiten betreffen. Diese Ergebnisse stehen weitgehend im Einklang mit Forschungsergebnissen zu den Auswirkungen populistischer Regierungen auf demokratische Strukturen.

\section{Introduction}

In their book on the rise of the far right, Benveniste et al. describe the emergence of populist parties in Europe in a peculiar way: "A ghost is haunting Europe, the ghost of "populism'" (Benveniste et al. 2016, p. 2). This is a paraphrase of a wellknown statement of Karl Marx announcing the imminent spread of communism in Europe amid the nineteenth century. While this does not represent accurately the development of the communist movement as envisaged by Marx, it is a precise description of the development of populism for the last 20 years. As Van Kessel indicates, at least 50 populist parties all over Europe have gained parliamentary representation since 2000 (Van Kessel 2015, pp. 71-2). The academic literature concerning this phenomenon is extensive. Some scholars focus on populism as an ideology (Mudde 2004; Mudde and Kaltwasser 2012), others on its discursive style (De la Torre 2000, p. 4), while some others study populism's strategies for mass mobilization (Madrid 2008, p. 482).

Furthermore, the relationship between liberal democracy and populism has provoked particular interest within the scientific community. A large body of literature has been written regarding this topic (Canovan 1999; Mény and Surel 2002; Mudde and Kaltwasser 2012; Rummens 2017). While some scholars are confident that populism can have positive effects on liberal democracy (Mudde and Kaltwasser 2012, pp. 20-1), many more point out an ideological clash between both (e.g. Pappas 2016, p. 29; Galston 2018, p. 11; for a more detailed account, see Chap. 2.2).

The relationship between liberal democracy and populism has been empirically explored through the analysis of Hungary. Fidesz, the ruling party from 1998-2002 
and once again since 2010 , has been categorized as a populist party by many researchers (Pappas 2014; Bozóki 2015, p. 30; Mudde 2016, p. 26; Halmai 2018). It has been argued that Fidesz' populist character has caused a democratic regression in Hungary and constitutes a serious challenge to the liberal foundations that underpinned Hungarian democracy (Halmai 2018, pp. 330-1; Pappas 2014, p. 5; Rydliński 2018, p. 97). The reforms carried out by Fidesz are based on the constitutional majority it won in 2010, which allowed the party to change the whole Hungarian legal system, including the constitution (Bánkuti et al. 2015, p. 38; Rydliński 2018, p. 97). The new constitution, enacted in 2012, has been regarded by some scholars as characteristic of an illiberal state (Halmai 2018, p. 331), as "not really democratic" (Bánkuti et al. 2012, p. 268), as a shift to a more authoritarian political culture (Pogány 2013, p. 366), and, in general, as a weakening of the system of checks and balances (Kovács and Tóth 2011, pp. 200-3) and a dismantlement of the rule of law (Vörös 2015, p. 199). The clash between the Hungarian government and the principles of liberal democracy is usually exemplified with an oftenquoted speech of Viktor Orbán, leader of Fidesz since the party's foundation and Prime Minister since 2010, in which he declared that "[w]e have to abandon liberal methods and principles of organizing a society. The new state that we are building is an illiberal state, a non-liberal state" (Viktor Orbán, cited in Buzogány 2017, p. 2; see also Akkerman 2017, p. 173; emphasis added).

More broadly, the criticism of the scholarly literature has tended to focus on specific areas such as the freedom of expression and press, the new electoral laws, the numerous unilateral appointments made to government positions by Fidesz, and, lastly, the separation of powers principle.

Firstly, according to several researchers, the freedom of expression and press has been attacked in Hungary through the centralization of independent media and the curtail of its financial resources, which makes the population dependent on Fideszoriented newspapers or government-controlled outlets for its sources of information (Schmidt 2018, p. 81). Furthermore, a reform of the media legislation created an organization (the National Media and Infocommunications Authority) focused on the supervision of private radio, television, print media and internet which is controlled and managed by another organ, the Media Council, whose chairperson is chosen directly by Prime Minister Orbán (Bajomi-Lázár 2015, pp. 60, 71). Outlets that do not follow the Media Law stipulations can be fined with high penalties (Ibid., p. 72). As some scholars have argued, because of the law's vague guidelines, the Media Council alone is responsible for deciding whether any media outlet has breached the statutes of the law (Pogány 2013, p. 363; Bozóki 2015, p. 20; Rydliński 2018, p. 98).

Secondly, the new electoral laws (Act CCIII of 2011 and Act XXXVI of 2013), which substantially modified the electoral system of Hungary, are criticized by the literature because of their partisan redistribution of electoral districts (Bozóki 2015, p. 20; Biró-Nagy 2017, p. 38; Kovács and Vida 2015, p. 63). For instance, Schmidt points out that Fidesz obtained $68.83 \%$ of the mandates with less than $45 \%$ of the votes in the 2014 elections as a result of the new electoral legislation (Schmidt 2018, p. 81). 
Thirdly, several researchers have noted that Fidesz has designated many party sympathizers in key positions of state offices (Pogány 2013, pp. 359-360; Bugaric 2014, pp. 9-11; Bozóki 2015, p. 19; Biró-Nagy 2017, pp. 37-8; Bogaards 2018, p. 1489). Bugaric, for instance, names seven important offices now led by Fidesz sympathizers: the Election Commission, the Media Council, the Presidency, the National Judicial Office, the Budget Council, the State Audit Office, and the Public Prosecutor (Bugaric 2014, pp. 9-11). These officials are appointed for long terms (usually for 6 or 12 years) and cannot be replaced without a two-thirds majority (Bugaric 2014, pp. 11-2; Bogaards 2018, p. 1489). Based on this, Bogaards categorizes Hungary as a future case of "democracy with reserved domains", which constitutes a democratic political system where elected officials cannot exercise their decision-making power because there are domains controlled by non-elected officials - or, as in this case, officials named by the previous government-who interfere with the execution of their duties. As Bogaards claims: "Fidesz might lose elections but can hold on to power through the counter-majoritarian institutions it created [and] the long-term appointments it made to key positions" (Bogaards 2018, p. 1489).

Lastly, it is argued that the legislative actions carried out by the party have eroded the separation of powers (Bugaric 2014, p. 8; Rydliński 2018, p. 98). As Bugaric maintains, the new constitutional order has invested so much power in the central executive that the checks and balances are not capable of restraining its power anymore (Bugaric 2014, p. 8). As a result, Hungary is considered a peculiar case of authoritarianism, because Fidesz has undermined the rule of law not by disrespecting the constitutional order but by changing it (ibid). Following this argument, Rydliński claims that the separation of powers "has been shaken to its foundations" (Rydliński 2018, p. 98) because of the continuous attacks upon the Hungarian Constitutional Court (henceforth: HCC).

Another set of criticisms comes from the quantitative indices of democracy, which provide a general picture of the abrupt backsliding of Hungarian democracy. For instance, the 2019 country report of Hungary by Freedom House downgraded the status of Hungary from "free", to "partly free" due to "sustained attacks on the country's democratic institutions by Prime Minister Viktor Orbán's Fidesz party”. As Freedom House suggests, this situation did not develop overnight but is the consequence of five consecutive years of "dramatic" democratic decline, as shown by the restrictions "on (...) the opposition, the media, religious groups, academia, NGOs, the courts, asylum seekers, and the private sector since 2010" (Freedom House 2019). Since 2019, the Freedom House score of the Hungarian democracy has slightly decreased, from 70/100 to 69/100, as measured in the 2021 version of the report.

The assessment of Freedom House goes in line with the results found by the Bertelsmann Stiftung in its Sustainable Governance Indicators project with respect to the quality of democracy in Hungary, which in 2020 ranked \#40 among 41 countries, just in between Poland and Turkey. The Hungarian score has declined from 5.1 to 3.4

\footnotetext{
${ }^{1}$ This concept comes originally from Merkel et al. (2003) and their work on liberal democracy, which is also the base of our framework.
} 
since 2014 primarily because of serious shortfalls in media access to elections, media freedom, political liberties and the rule of law. Significantly, the key findings of the report highlight the control of media outlets by the government, the harassment to which opposition supporters are subject during political campaigns and the overall decline of judicial independence (Ágh et al. 2020).

After this general review of the literature on Hungary, a central remark must be made. A key issue with much of the qualitative research on the effects of Fidesz in Hungary is the neglect to contrast the political reforms with democratic theories that focus on the comparison of political systems. Bogaards (2018) is a notable exception, since he evaluates the changes introduced by Fidesz with a liberal democratic framework. In fact, the base of the author's approach is the work of Merkel et al. on embedded democracies, which constitutes the basis of our own approach. However, the study of Bogaards suffers from an important pitfall: there is no operationalization of the criteria of Merkel et al., which leads to non-supported conclusions. It is claimed, for instance, that the extension of voting rights to Hungarians living abroad-a provision conferred by the new electoral laws-constitutes a "problem" for the right to active suffrage (Bogaards 2018, pp. 1485-6). The reason of this, however, remains unclear. Intuitively, we would argue that the extension of voting rights improves the quality of the electoral system because the respective democracy becomes more inclusive. In this study, we try to overcome the limitations of Bogaards' approach by introducing an operationalization of Merkel's criteria (see Chap. 3).

Framed this way, this article aims at filling a theoretical void in the literature, which is the lack of comparison of the political reforms in Hungary with the principles of a democratic theory. In our view, this qualitative, comparative approach has not been applied by other scholars. In fact, as the studies of Byró-Nagy (2017), Bánkuti et al. (2012, 2015), Scheppele (2013, 2014) and Ágh (2013), Bozóki (2015) do, the research has tended to focus rather on the description of the new political developments than on their consequences on the Hungarian democratic system. However, even when these consequences are discussed, the refusal to use a framework to analyze changes in democracies has led to vague and flawed conclusions. In other words: we do not know if, how, and in what way the discussed reforms debilitate the democratic system of Hungary.

The research questions that guide this paper are whether some dispositions of the newly enacted Hungarian Fundamental Law, the Hungarian constitution, are indeed violations of liberal democratic principles, as the literature states, and, if that is the case, whether these are linked to the populist character of the Fidesz government. These questions are appropriate to explore the actions of Fidesz in government, since the introduction of the new constitution is the most important institutional change that the ruling party has undertaken.

To answer our research questions, this paper is divided into five sections. In the next segment we propose a framework to explore institutional changes in liberal democracies. As mentioned above, the base of our approach is Wolfgang Merkel 
et al.'s concept of embedded democracy ${ }^{2}$, which we contrast with central elements of populist ideology, especially the relationship between majoritarian decision-making and liberal democratic institutions such as the constitution. Subsequently, in the third section the design and method of the study are presented, which include our operationalization of Merkel et al.'s criteria. Based on this, we finally examine five changes of the new Fundamental Law in comparison with the old one, as well as two transitional provisions of the constitution which also deserve our attention, as we show later. Some conclusions are drawn in the final section.

\section{Liberal democracy and populism}

\subsection{The concept of liberal, embedded democracy}

Merkel et al. argue that the core of democratic rule is the sovereignty of the people, which means that the demos either directly rules or decides how it is supposed to be ruled (Merkel et al. 2003, p. 40). This is known as vertical legitimacy, which is based on the principles of political equality and political freedom of all members of society (Ibid., pp. 41-2).

Nevertheless, democratic rule needs to be limited, so no temporary majority can override these basic principles. That is why constitutionally defined constrains on democratically elected organs at the horizontal level are required (Ibid., p. 43). Moreover, since a liberal conception of democracy recognizes the separation between political and civil life, the establishment of institutions that prevent state intrusions into the private life of citizens is also necessary (Ibid.). Finally, for a democratic rule to exist, it is essential that elected rulers are the ones who actually exercise the power invested in them, and not other actors (Ibid., p. 47).

In conclusion, Merkel defines liberal democracy as a three-dimensional concept, namely:

Democracy' (short for liberal democracy based on the rule of law) is to be defined as a set of institutional minima, which firstly signifies a vertical dimension of democratic rule, namely vertical power control, universal active and passive suffrage and the effective guarantee of the associated fundamental rights of political participation; secondly, a horizontal dimension, i.e. control of power within the framework of the organization of the state based on the separation of powers and the exercise of rule based on the rule of law; thirdly, a transversal dimension, i.e. the effective assignment of governmental power to the democratically legitimated rulers (Ibid., p. 47, own translation).

Merkel et al. disaggregate these three dimensions into five central elements of democracy, named partial regimes (Ibid., p. 57). The electoral and the political rights

\footnotetext{
2 The term embedded democracy is used interchangeably with liberal democracy by Merkel (Merkel 2004, p. 36). Merkel et al. employ the term "liberale rechtsstaatliche Demokratie", which can be loosely translated to liberal, constitutional democracy. When we use liberal democracy as a concept, we refer to the use of Merkel (2004) and Merkel et al. (2003, p. 47).
} 
regimes form the vertical dimension, the civil rights and the separation of powers principles the horizontal dimension, while the effective power to govern represents the transversal dimension:

- Electoral Regime: In a democracy, the public power positions depend on the results of open, competitive elections (Merkel 2004, p. 38). This regime guarantees the principles of sovereignty, political equality and political freedom and its existence is based on four criteria: (1) universal active suffrage, (2) universal passive right to stand for election, (3) free and fair elections, and (4) elected representatives.

- Political Rights: These refer to political rights that go beyond the right to vote. Their principal function is the formulation and organization of demands and preferences in the public arena (Ibid.). Political rights are constituted by the freedom of the press, speech and opinion, as well as by the right of association, demonstration and petition.

- Civil Rights: The civil rights regime protects the citizen from interferences of external actors in his private life. More specifically, this regime is closely related to the rule of law in democratic systems, i.e. "the principle that the state is bound to uphold its laws effectively and to act according to clearly defined prerogatives" (Ibid., p. 39). The criteria that guarantee this regime are, first, the existence of rights that protect the individual against state and private actors and, second, the equal treatment by and equal access to courts (Merkel et al. 2003, p. 57).

- Division of Power and Horizontal Accountability: The goal of horizontal accountability is to prevent self-perpetuation or abuse of power by one branch of government, which implies that "elected authorities are surveyed by a network of relatively autonomous institutions" (Merkel 2004, p. 40). In this sense, the state organs "check each other reciprocally [...]" (Ibid., p. 41). The only criterion for this principle is the existence of the separation of powers (Merkel et al. 2003, p. 57).

- Effective Power to Govern: The last regime requires that democratically elected representatives are the ones who actually govern. Therefore, extra-constitutional actors, such as the military, cannot make final decisions in certain policy domains that are restricted to democratically elected rulers (Merkel 2004, pp. 41-42). The only criterion here is the presence of elected officials with real power (Merkel et al. 2003, p. 57).

The concept "embedded democracy" implies that the discussed regimes are embedded in the sense that some support the functioning of others (e.g. political rights and civil rights support the electoral regime), whereas at the same time, some others guarantee that certain political actors do not infringe on the functional spheres of other regimes (Horizontal Accountability, based upon mutual control between branches of power, is the example that most easily comes to mind). Framed this way, democracy is "a complex of interdependent and independent partial regimes" (Merkel 2004, p. 43). In this sense, the division of democracy into partial regimes has an important analytical advantage since it enables a "precise determination of the location of defects within a democracy" (Ibid.). If one of the regimes is damaged 
to the point of breaking the embeddedness of the system, Merkel et al. refer to it as a "defective democracy" (Ibid., p. 48).

Even though defective democracies are political systems where the partial regimes are no longer mutually embedded, these systems are still considered democratic, which implies that they conserve a minimum of freedom, equality, and control of elected officials. In this sense, the key differences between a defective democracy and an authoritarian regime ${ }^{3}$ are, firstly, that in the former, rulers can lose power through competitive, inclusive, and free elections. Secondly, in contrast to an authoritarianism, a defective democracy implies a minimum of horizontal and vertical control $^{4}$ (Merkel et al. 2003, p. 67).

Depending on which partial regime is damaged, four subtypes of defective democracy can be identified. Malfunctions of the electoral and/or political rights regime lead to an exclusive democracy; defects of the civil rights regime to an illiberal democracy ${ }^{5}$. A delegative democracy is one where the horizontal accountability does not function properly. Finally, if there are non-democratically elected vetopowers that make decisions in certain policy fields, a domain democracy emerges (Ibid., p. 69).

Now that we have outlined the concept of liberal democracy by Merkel et al., we address the argument why populist parties can be expected to pose a threat to liberal democracy.

\subsection{Relationship between liberal democracy and populism}

The literature concerning the relationship between liberal democracy and populism is extensive and ambivalent. For instance, Cas Mudde and Rovira Kaltwasser count at least 6 positive effects that populism can have on liberal democracy, which include giving voice to groups not represented by the elites, mobilizing excluded sectors of society and increasing democratic accountability (Mudde and Kaltwasser 2012, p. 21). Following this argument, Kaltwasser, in another work on this topic, argues that populism fosters the political participation of disadvantaged groups by including them in the political arena, especially in societies with low levels of inclusion, to be found tipically in Latin America (Kaltwasser 2012, pp. 197-8). However, both Mudde and Kaltwasser are aware that the relationship is not unequivocally positive. Populism, based on the incontestable power of popular sovereignty, also undermines the checks and balances, the separation of power, and the protection of minorities (Mudde and Kaltwasser 2012, p. 21). Populists reject "a conception of democracy based on the idea that the rule of law, division of power through checks and balances, and constitutionalism are essential for the protection of individual rights" (Akkerman

\footnotetext{
3 We use authoritarianism as a concept that encompass all types of non-democratic rule.

${ }^{4}$ A key remark needs to be done here. Merkel et al. do not offer a concrete definition of authoritarianism along their theory, which we consider a weakness of the theory. Nevertheless, the authors define thresholds (Schwellen) where a defective democracy can be distinguished from an authoritarianism (Merkel et al. 2003, pp. 73-95).

${ }^{5}$ Here it is important to emphasize that, in the authors' understanding, deficits in other sub-regimes can also be violations of principles of liberal democracy. However, they do not name these defective democracies as illiberal altogether.
} 
2017, p. 170). In this sense, several scholars have drawn the conclusion that the populist ideology inherently opposes not democracy per se but its liberal version (Plattner 2010, pp. 87-8; Galston 2018, pp. 5, 11; Pappas 2016; Huber and Schimpf 2018, p. 330).

The core of this argument stems from the assumption that liberal democracy tries to achieve two competing goals: majority rule and protection of minorities (Plattner 2010, p. 84). According to Huber and Schimpf, liberal democracy implies an "internal struggle for balancing popular rule, on the one hand, with anti-majoritarian constraints, on the other" (Huber and Schimpf 2018, pp. 330-1). Mény and Surel state a similar argument as they maintain that there is an inherent tension within democratic rule, in specific between the power of the people and the constitutional provisions that protect the citizen and prevent the arbitrary exercise of power (Mény and Surel 2002, p. 7). The clash between populist movements and liberal democracy arises because the formers "behave as if democracy meant the power of the people and only the power of the people" (Ibid., p. 9-italics in the original), and therefore disrespect constitutional institutions. Framed this way, populism does not question the majoritarian side of democracy ("government of the people, by the people, for the people", which represents, according to Canovan 1999, p. 10, the redemptive side of democracy - 1999, p. 10), but tries to undercut political institutions which, from the populist standpoint, hinder the proper implementation of the general will (Huber and Schimpf 2018, p. 332).

For populists, the world is divided between a homogeneous and virtuous community, i.e. the people, and a powerful, decadent group, i.e. the elite. In the populist's view, the democratic rule should be based merely on the will of the "people", which is understood as a uniform, virtuous, and homogenous group, whose members share the same values and interests (Galston 2018, p. 12). As Mudde and Kaltwasser note, "the people" and "the elite" are two concepts that constitute "empty vessels", which conveys the notion that, depending on the populist movement, the people and the elite are defined differently (Mudde and Kaltwasser 2013, p. 151). In this sense, it is useful to follow the distinction of "the people" made by Galston, since he maintains that historically, "right-leaning populists have emphasized shared ethnicity and common descent, while left-leaning populists have often defined the people in class terms, excluding those with wealth and power" (Galston 2018, p. 12). On this account, if populists focus on ethnicity as a reason to "expel" groups or individuals from the imagined "people", Bergmann speaks of "nativist populism" (Bergmann 2020, pp. 38-9).

Based on these accounts, we expect the governments formed by populist parties, such as Fidesz in Hungary, to make changes mainly to the institutions that can serve as counterweights to majority decisions, which are the ones guaranteeing the division of power, such as the judicial system. That is why we concentrate our analysis on this area, which, theoretically, should be the first one affected by the institutional changes of the ruling party. Moreover, since the proponents of populist ideologies assume a homogenous people, they are rather critical of individual and minority rights. This is even more pronounced in the case of radical right-wing populist parties (RRPPs), which are defined by Mudde as political parties whose core ideology is a combination of nativism, authoritarianism, and the already discussed concept 
of populism (Mudde 2007, p. 26). For their nativist character, RRPPs consider non-native persons as a threat to the homogeneous nation-state (ibid., p. 17-19). Accordingly, it is likely that, when in government, RRPPs curtail the rights of these groups (on the classification of Fidesz as a RRPP, see also Ádam and Bozóki 2016 and Hegedüs 2018). Our second focus therefore lies on the civil rights regime.

These theoretical reflections do not give insight into how the presumed changes can be identified. The next section deals with this question. As it is shown later, in order to document breaches of liberal elements within a democracy, we need to create indicators that translate the previously discussed concepts by Merkel et al. into observable entities. In other words, an operationalization of Merkel et al.'s criteria is essential. Afterwards, based on this framework, we examine five changes of the newly enacted Hungarian Fundamental Law and two transitional provisions.

\section{Research design}

As mentioned above, this study provides an in-depth analysis of seven new provisions that are included in the new Hungarian constitution. To be able to do so, we elaborated a framework that can be used to analyze institutional changes in liberal democracies, which is based in the criteria developed by Merkel et al. that underpin the concept of embedded democracy (Appendix A). As these criteria are too general for an empirical analysis, our approach consists of operationalizing them into indicators by transforming general concepts into several, more specific questions (Appendix B). We use this tool to analyze the new dispositions of the Hungarian constitution. In this sense, we assume that certain institutional changes can break the embeddedness of the Hungarian political system, thus transforming it into a defective democracy. When this occurs, we refer to the respective institutional change as a violation of liberal democratic principles.

The mentioned questions are framed in a way that only allow dichotomous answers (either affirmatively or negatively). In this framework, every affirmative answer (every "yes" to a question) represents a backslide from a previously superior position (i.e. from a "more democratic" position). When we observe that an institutional change somehow affects one of the embedded democracy criteria, we proceed with the second step of our approach, this being to qualitatively examine the particular case more closely to determine how serious the change is. At this point, we employ the thresholds (Schwellen ${ }^{6}$ ) developed in the embedded democracy theory as our main theoretical tool, as well as several comparative analyses with other democratic countries, to argue whether the respective case (by itself) break the embeddedness of the Hungarian political system. In the final discussion, we analyze

\footnotetext{
${ }^{6}$ For each of the embedded democracy's regime, Merkel et al. (2003) developed thresholds to distinguish fully liberal democracies from defective democracies, and these in turn from authoritarian systems. As conceded by Merkel et al., the embedded democracy's theory is not exempted from typical issues of operationalization in democratic research, such as the precise differentiation between democratic and authoritarian regimes; the weighting of indicators in research and the subjective role that the researcher plays while doing research (Merkel et al. 2003, pp. 74-6). To counteract these issues, we compare the Hungarian case to other democratic regimes in our argumentation, which inevitably puts these reforms in context.
} 
these changes together. At this point, it is important to emphasize that what we define as backslide does not necessarily imply a violation of democratic principles. There are institutional reforms that do not affect the constitutional system in such a far-reaching manner.

We define institutional change in accordance with the concept of institutions of Mahoney and Thelen (2010). In this sense, institutions are relatively enduring structures of political and social life (such as norms, procedures, or rules) that influence behavior (Ibid., p. 4). Therefore, an institutional change is defined as a modification of these structures. Subsequently, we examine institutional change in Hungary by focusing on the differences between the old constitution and the new Fundamental Law. This is because the introduction of a new constitution was the most significant institutional change that Hungary has undergone since Fidesz' rise to power. The data we use is based on both the new and the old constitution itself as well as secondary sources taken from the respective legal literature.

\section{Five changes to the Hungarian fundamental law}

The literature on Hungary provides several constitutional novelties that are criticized for their effects on the democratic system. For our selection of cases, we have chosen the changes that were critically reviewed in two or more sources of the literature, some of which were already mentioned in the introduction. Together with a previous work on this issue, they represent a comprehensive view of the constitutional changes that have been carried out since 2012 (Gómez 2020). We start with the constitutional articles that concern the partial regime of the separation of powers. Based on previous assessments by other scholars, this seems to be the most altered of the five regimes for the Hungarian case after the introduction of the new constitution. Afterwards, we consider two more changes, one concerning the Civil Rights regime and the other affecting the Effective Power to Govern regime.

Before moving to the analysis, an important remark must be made. Interestingly, the analyzed changes concern only three partial regimes: Division of power, Civil rights, and Effective power to govern. The Electoral regime and the Political rights regime were not influenced by the reforms discussed here, which does not mean that Fidesz government has not changed them in any way. In fact, as discussed above, the Hungarian Parliament enacted new electoral laws that have been highly criticized by the literature. The fact that they do not enjoy constitutional rank does not reduce their importance; however, as our object of study is the new constitution, we include here only the reforms made at the constitutional level (see Fundamental Law of Hungary 2011). 


\subsection{Division of power and horizontal accountability}

\subsubsection{New appointment method of the constitutional court's president}

The previous constitution assigned the HCC the power to designate its own President. Under the new constitution, according to the article 24, a two-thirds majority of the Parliament chooses the Court's president for a period of twelve years.

This change is included in the separation of power dimension because it involves the relationship between two branches of government. In a nutshell, it increases the competences of the legislative organ and reduces the rights of the judiciary. Moreover, the appointment of the court's president by the legislature reduces the independence of the HCC, since it cannot choose its own head.

In this case, a change in the relationship between two or more branches of power should not be necessarily regarded as a violation of liberal principles, even if it involves a shift in the power structure. Rather, the central question is whether the identified change actually violates the division of power principle. As Merkel et al. note, a functional separation of power regime implies that no power may dominate or influence the constitutionally determined core areas of another (2003, p. 54). This would be the case if the core idea of the regime-here, the mutual control of institutions to prevent a potential abuse of power by one of the branches of government-is violated or at least considerably restricted. The question is, then, whether the shift in the appointment of the President of the Court to the Parliament has limited the exercise of the separation of powers or not. Framed this way, we believe that neither the core competencies nor the independence of the Court are compromised as a result of this change since the President does not enjoy appreciable rights vis-à-vis his fellow justices or other state organs, nor he/she has the faculty to exercise legislative or executive functions besides his/her role as head of the court. As a consequence, the functions of the Court within the separation of powers, which encompass primarily the control of the government and parliament, are not notably affected. In other words: the selection of the President does not reduce the control options of the judiciary towards other branches of power. Although Kovacs and Toth list this amendment in the context of provisions that "seem" to limit the independence and powers of the HCC, they do not explain to what extent this occurs as a result of this specific amendment (Kovács and Tóth 2011, p. 200).

\subsubsection{New selection method of the constitutional court's judges}

In Hungary, as in many other political systems in the world, the election of a justice for the Constitutional Court requires a two-thirds majority in Parliament. However, before the election, a nomination process takes place, which is defined in the constitution. Concerning this, Fidesz introduced an important change in the new constitution. The old constitution stipulated in article 32/A paragraph 4 that a subcommittee of the National Assembly proposed candidates for an HCC Judgeship. The subcommittee consisted of one member of each party represented in the National Assembly and decided by a two-thirds majority. Therefore, as long as there was at least an equal number of parties in the opposition and in the government 
(as it was the case in Hungary since 1990 except for the 2002-2006 period), or not enough parties in the government to form a two-thirds majority in the subcommittee, the opposition parties were likely to be included in the search for candidates.

Now, under article 24 of the new constitution, the nominees still need a two-thirds majority in the subcommittee, but the composition of the latter is defined differently. Currently, the subcommittee's composition "must reflect the relative strength of the parties in parliament", which, according to Vörös, guarantees that Fidesz, enjoying a two-thirds majority since 2010 and at least until the next election (to take place in 2022), de facto nominates all the candidates (Vörös 2015, p. 188).

We consider this change to concern the separation of power principle, because, as the previous change, it refers indirectly to the relationship between two branches of government, although formally it only relates to the process of selecting candidates within the Parliament. In this respect, some scholars have criticized this change, arguing it weakens the HCC (Bánkuti et al. 2012, p. 254). Vörös suggests that the nomination process of the old constitution ensured "that both the current government and the opposition could nominate roughly equal numbers of judges". Following this argument, by changing the composition of the subcommittee, the government ensured that only persons nominated by the ruling party are elected as justices. Therefore, "the composition of the Constitutional Court has been significantly altered, even distorted" (Vörös 2015, p. 188).

Taking a step back and looking at the theoretical foundations of our analysis, a judge selection method is not specifically preferred over others by the embedded democracy theory. Instead, the central element for the analysis of an effective separation of power within a democracy is the judicial independence of courts and similar institutions. The model underlines that judges cannot be used for political purposes nor be influenced so that they cannot be impartial in their verdict anymore (Merkel et al. 2003, p. 90). In this sense, the new selection method does not necessarily lead to a weaker judicial independence, as exemplified by other countries having similar selection methods for their constitutional courts. In Germany, for instance, an "electoral commission", formed proportionally from the strength of the parties in the Parliament, nominates the candidates for a Judgeship (both in the Bundestag and in the Bundesrat). In fact, by requiring a $2 / 3$ majority both in the nomination and the selection processes, Hungary goes beyond the requirements of most political systems, where a simple majority is the usual requirement for selecting judges to the highest courts (as documented by Kneip 2016, p. 367). In our view, since the current requirements of nomination and appointment of HCC justices follows a rather standard practice in other functional constitutional democracies, it alone is not detrimental to the mutual control or to the independence of the judiciary envisaged as the prime conditions for a functional separation of powers.

The problem that arises from this change is not the new requirement per se, but the fact that Fidesz has enjoyed a two-third majority in the Parliament since 2010 and can alone determine the candidates for the Court. In other countries, the selection of the members of the highest court usually follows a political dialogue among several parties, which at the end counterweighs and balances possible political influences. The absence of this dialogue may indicate that the loss of judicial 
independence documented by other scholars and democratic indices is not a product of new legislation, but its combination with the current Hungarian political context.

\subsubsection{Constitutional court's competencies concerning budgetary issues}

The review faculty of the HCC concerning budgetary issues was also modified with respect to the previous Basic Law. The new constitution stipulates that the Court may fully review and take actions on laws concerning public finances only if the state debt is lower than $50 \%$ of the GDP. When the state debt is higher, the competencies of the HCC are limited by article 37 IV of the newly enacted constitution. When this threshold is surpassed, the HCC has the right to intervene solely in the case that newly promulgated laws violate the right to life and human dignity, the protection of personal data, freedom of opinion and conscience or the rights associated with Hungarian citizenship ${ }^{7}$. In our framework, we place this change into the separation of power regime for concerning primarily the HCC.

The scholarly research has extensively criticized this new provision on the grounds that it reduces previous competencies of the HCC. Since the previous constitution did not specify the areas subject to the HCC jurisdiction, it was assumed both by the literature and the Court, that the HCC enjoyed far-reaching attributions regarding budgetary legislation, regardless of the level of public debt (Kovács and Tóth 2011, pp. 201-2; Bánkuti et al. 2012, pp. 254, 261; Jakab and Sonnevend 2013, pp. 123-4; Vörös 2015, p. 183). In this sense, the new provision limits previously comprehensive faculties and delimits it specifically to several constitutional rights. However, according to Bánkuti et al., this leaves out areas that are likelier to be affected by public finances laws, such as "the right to property, equality under the law, the prohibition against retroactive legislation, or the guarantee of fair judicial procedure" (Bánkuti et al. 2015, p. 39; see also Vörös 2015, p. 180). In this respect, the model of Merkel et al. stipulates that liberal democracies unavoidably require the "exercise of judicial supervision over the compatibility of legislation (...) with the formal and substantive content of the constitution" (2003, p. 90; own translation). The new legislation effectively strips out areas from the judicial review performed by the HCC. Therefore, in the same vein as the literature, we argue that this change reduces the control options of the judiciary towards other branches of power, its competencies, and its enforcement power. Putting it in contrast to Merkel et al. model of democracy, the disposition that the HCC can only fully intervene when the state debt falls under $50 \%$ de facto eliminates this area of its competencies and is therefore detrimental to the separation of powers in Hungary ${ }^{8}$. Because of these reasons, we consider it as a violation of liberal democratic principles.

\footnotetext{
7 It is not likely that the state debt, now standing at $84.5 \%$, will fall below $50 \%$ in the foreseeable future. Even more importantly, according to data provided by the OECD, the state debt of Hungary has never fallen below 50\%, at least since 1995 (availability of data starts in this year-see OECD 2020).

8 The rationale of the government for this change was, according to Küpper, the improvement of implementation of fiscal policy. Why the HCC would impede proper fiscal measures on grounds of unconstitutionality was, however, left unexplained (Küpper 2012, p. 93).
} 
In this case, the weakening of checks and balances (in this case, the reduction of the HCC competences) is a characteristic trait of governments formed by populist parties such as Fidesz in Hungary. Notably, in their study of ruling populist parties in Poland, Austria, Switzerland and Italy, Albertazzi and Mueller find that continuous attacks to the separation of power principle have not been an exception but the norm. Here, populist parties have either shown a lack of respect for courts (in Austria), tried to curtail the power of courts (in Italy) (also found by de Ghantuz Cubbe 2021), reduced the independency of the judiciary in general (in Poland) or called for the use of majoritarian practices, such as referendums, to disregard decisions of courts (in Switzerland-see Albertazzi and Mueller 2013). This goes in line with the findings of Huber and Schimpf, who argue in their study of 30 European countries between 1990 and 2012 that populist parties are negatively associated with mutual constrains, understood as the balance between the branches of government and the power of the judiciary to review political decisions (2017, p. 151). On this basis, it becomes clear that populist governments disregard the importance of checks and balances and seek to reform institutions that serve as counterweights to majority decisions, as was expected from the theoretical account we discussed above.

\subsection{Civil rights-Abolishment of the right of every citizen to appeal to the constitutional court for a judicial review}

The previous constitution gave every citizen the right to appeal to the HCC for an ex-post constitutional review over any matter, which was stipulated by the former article 32/A paragraph 3. The new constitution allows revision of judicial, legislative, or executive decisions only if personal involvement can be proved (article 24 paragraph 2).

We consider this change to be part of the civil rights regime since it involves a mechanism that citizens might use to protect themselves from other actors. Before the promulgation of the new constitution, there was a particularly unusual kind of "vertical division of powers" carried out by every citizen. This is unknown in other political systems. In Germany, for instance, only the constitutional bodies can request the Constitutional Court to perform this abstract review of legislative acts (abstrakte Normenkontrolle). In this sense, the rights of Hungarian citizens now resemble the judicial rights that German citizens enjoy (Verfassungsbeschwerde), which stipulate that each citizen can only appeal to the German Constitutional Court against acts by state powers if he believes his constitutional rights are being violated by them. Equally, the new Hungarian basic law only limits the ex-post revision to topics involving the individual that appeals. The liberal democratic model of Merkel et al. indicate that a democracy is defective in this regard when either "individual rights against governmental and private actors are not secured or are severely restricted" or when individuals do not have free and equal access to the courts to claim their rights (Merkel et al. 2003, p. 86). This does not seem to be the case with this change as individuals are still protected by the Constitutional Court if their rights were somehow violated.

Therefore, we argue that the abolishment of the actio popularis does not constitute a violation of the civil right regime because it does not decrease the protection of 
individuals. Similarly, Küpper goes one step further and argues that this change actually strengthens the HCC since its capacities can now be used for other, more urgent, matters (Küpper 2012, pp. 93-4).

\subsection{Effective power to govern-Creation and competencies of the budget council}

Under article 44, the Fundamental Law creates a new organ in charge of examining the "feasibility" of the state budget. More specifically, it must consent the adoption of any new budget proposal passed by the Parliament before its promulgation, and it must ensure that the proposal does not increase the national debt. The Budget Council, as it is called, consists of three members, including its own president, who is named by the President of the Republic. The other two members, the President of the National Bank of Hungary and the President of the State Audit Office ${ }^{9}$ are officials selected by the President of the Republic and Congress, respectively. The approval of the annual budget by the Budget Council is of crucial importance because if no national budget is approved by March 31 of each year, the President of the Republic can dissolve Parliament and call new elections based on article 3 of the constitution (Bánkuti et al. 2012, p. 263; Jakab and Sonnevend 2013, p. 120; Vörös 2015, p. 183).

Merkel et al. propose to analyze these types of changes by considering the question whether there are "reserved domains" that are excluded from the democratic decision-making process. If the political powers of democratically elected organs are curtailed by unelected officials, then the respective democracy is defective. This situation may arise by a lack of competencies of the parliament (Kompetenzarmut eines gewählten Parlaments) or by broad control of political domains by non-elected officials (see Merkel et al. 2003, p. 92).

Analyzed this way, the creation of the Budget Council is detrimental to the state of democracy in Hungary for several reasons. Firstly, the fact that three unelected officials, who have longer office terms than the Parliament ${ }^{10}$, have such a strong influence over the state budget reduces the budgetary competences of future parliaments. Assuming a scenario where Fidesz has appointed loyalists to the Budget Council and the opposition wins next elections, this new government will be constrained by the Budget Council since Parliament cannot decide alone over the official budget, leading, as Merkel et al. exposed, to a lack of competence (Kompetenzarmut) of the most important political organ in Hungary.

Furthermore, if no national budget is approved by 31 March each year, the Hungarian President has the right to dissolve Parliament and call for new elections. The lack of budgetary independency of the Parliament would give Fidesz a new opportunity to re-win a majority needed to form a government. In this respect, we share

\footnotetext{
9 The State Audit Office is, according to the Article 43 of the Constitution, the Congress' financial and control body.

10 The State Audit Office's President is elected by a two-thirds majority in the Parliament for twelve years (Fundamental Law, Article 43). The President of the Republic designates the President of the Budget Council and also the President of the National Bank for six years (Fundamental Law, Article 41 and 44).
} 
the worries of the literature and regard this change as an attack on liberal principles because it deprives future governments of the effective power to govern (Küpper 2012, p. 97; Vörös 2015, p. 183).

The creation of the Budget Council was not expected from the theoretical account exposed in the second part of this study. The new organ does not seem to weaken judicial counterweights or undermine civil rights, which were our main expectations from populist parties in government. Surprisingly, it seems to be rather a widening of checks and balances, as the hurdles for adopting the national budget are now higher than before. However, when this change is analyzed more closely, it becomes clear that the supposedly broader checks and balances do not intend to widen constitutional counterweights but rather introduce a new key veto-player, whose significance will be central if Fidesz loses a future election. This reasoning lies on the fact that the members of the council were chosen by the Fidesz supermajority and have longer terms than the Hungarian Parliament. In this regard, what seems like a strengthening of democratic procedures is actually an attempt to restrict the functioning of future governments. As in the case of the new selection method of Justices for the Constitutional Court, the true purpose of this change is understood when the current political situation in Hungary is included into the picture. Seemingly harmless reforms add up to cement the ruling of Fidesz within Hungary.

\subsection{The transitional provisions ${ }^{11}$}

Even though the transitional provisions were not originally part of the constitution, the Fundamental Law's first amendment, enacted six months after the promulgation of the new constitution, gave them constitutional rank. Two of these provisions deserve a closer look.

\subsubsection{Creation and competencies of the national office for the judiciary}

Before the promulgation of the Fundamental Law, ordinary courts had a system of self-administration. Afterwards, based on the constitution transitional provisions' article 11, this system was abolished and a new institution for court administration was created, the National Office for the Judiciary (NOJ). The president of this organ is chosen by Parliament with a two-thirds majority for a term of nine years. Among his competences was a provision that allowed him to reassign specific cases to specific courts ${ }^{12}$. Moreover, he can remove judges or name new ones at will. The National Judicial Council, which is also a new body, has the task to supervise the actions of the NOJ's President but cannot dismiss him. Its role is merely advisory. We

\footnotetext{
11 These provisions were enacted as a body separated from the constitution on 30 December 2011 and aimed at dealing with temporary issues in the period between the suspension of the old constitution and the entry into force of the new one. Nevertheless, they regulate more complex issues such as the ones explored here (For a comprehensive discussion on the character of the transitional provisions, see Jakab and Sonnevend 2013, pp. 116-118).

12 According to the account provided by Vörös, both the European Parliament and the Venice Commission sharply criticized this provision. Accordingly, the fifth amendment, enacted in September 2013, deleted this regulation from the Fundamental Law (Vörös 2015, p. 187).
} 
consider this to be a change within the separation of power sphere, since it influences the administration and functionality of the judiciary through a new legislatively formed, but de facto executive institution (Bánkuti et al. 2012, pp. 262-3; Jakab and Sonnevend 2013, p. 117; Vörös 2015, pp. 186, 189).

As mentioned above, the framework of Merkel et al. states that attacks to the separation of powers regime come in part from lack of judicial independence, since judges cannot be impartial in their verdicts if they are subject to political pressures. In this sense, judicial independence encompasses two factors: organizational and political independence (Merkel et al. 2003, p. 90).

In our view, by eliminating the system of self-administration and replacing it with an executive body, the organizational independence of the judicial branch is compromised. The career paths of judges are now determined solely by the President of the NOJ, leaving judges dependent on his/her considerations. This breaks away the protection of judges against "any threats, interference, or manipulation which may either force them to unjustly favor the state or subject themselves to punishment for not doing so", which Merkel et al. consider to be the cornerstone of judicial independence (Larkins 1996 cited in Merkel et al. 2003, p. 90).

We regard the elimination of the Courts' self-administration system as a violation of liberal democratic principles because it curtails the judicial independence for the benefit of other powers, specifically the legislature. Furthermore, even more problematic for the Hungarian democracy is the influence that the NOJ's President can exercise over the judiciary. Based on the current majority it enjoys, Fidesz could directly influence the acceptance or removal of judges by appointing an official with close ties to the party. Framed this way, verdicts favorable to Fidesz can be expected. It becomes clear that the coalescence of these conditions is what generates a more alarming situation for the independence of the judiciary in Hungary.

The creation of an executive institution that may negatively influence judicial independence goes in line with the discussion of populism developed above. The populist understanding of democracy does not include the existence of checks and balances that protect constitutional rights as the people is homogeneous and its general will, uncontroversial. As mentioned above, several populist governments have weakened their own checks and balances through various ways, but they share a common characteristic: As courts have been weakened, the executive power has grown stronger. Huber and Schimpf offer a concise summary of this situation:

Most populist parties regularly call for changes to the constitution to empower the executive. Parties on the left (...) have voiced similar demands to those on the right (...). Each of them has demanded more power for the ruling executive to shift power away from parliaments and courts (Huber and Schimpf 2017, p. 149)

\subsubsection{New recognition method of religious communities}

Before the promulgation of the new Basic Law, religious communities would seek recognition as churches before a court of law. The article 21 of the newly enacted constitution's transitional provisions stipulates that religious communities must seek 
recognition before Parliament. Moreover, according to the Parliamentary Act 100 of 2011, the requirements for being recognized are now higher: whereas the old constitution prescribed a minimum of 100 petitioners for the recognition, the Fundamental Law increases this number to 1000 and also requests a twenty-year presence in Hungary (or 100 years of international operation). Parliament is not obliged to grant it and can submit it for a vote (Uitz 2012, pp. 931-2; Vörös 2015, p. 191).

The model of Merkel et al. considers that one of the minimal criteria for liberal democracies is the prohibition of discrimination of cultural, linguistic, or religious minorities, which must be guaranteed both by the legal framework and by free and equal access to courts, as was mentioned above (Merkel et al. 2003, pp. 85-6). The new disposition for recognizing religious communities disregards these considerations by increasing the recognition requirements and by leaving the decision of recognition to a political organ such as the parliament. We consider this a clear and direct violation of the civil rights of minorities in Hungary. Through this way, recognition is transformed into a political question and the decision is left to the majority of the moment, as Vörös and the HCC argue (Vörös 2015, p. 191).

The relation between populist parties and minority rights has received a vast attention from the literature. In general, the effects of populist parties, especially rightwing populist parties, tend to be detrimental to minorities, which is to be expected from the theoretical discussion developed above, as per definition, a homogeneous people preclude the existence of minorities. Consequently, right-wing populist parties have maintained that the cultural and ethnic homogeneity of the people is being threatened by minorities whose values are incompatible with those of the people (Spittler 2018, pp. 100-1). Empirical analyses of the effects of populist parties in liberal democracies indicate that RRPPs have either lowered the quality of representation for minority groups (Ibid., p. 112) or directly approved anti-minority policies, as in Italy against Roma and Islamic communities and in Poland against homosexuals (Albertazzi and Mueller 2013, pp. 353-64). For left-wing populist governments, such effects are not documented, which hints at the importance of the host ideology for analyzing populist governments (Huber and Schimpf 2017, p. 151). In this sense, the developments in Hungary since the rise to power of Fidesz tend to confirm the correlation between the weakening of minority rights and right-wing populist governments.

\section{Summary and conclusion}

The scientific community categorizes Hungary as a case of democratic regression since Fidesz's rise to power in 2010. However, most of the studies do not provide an analytical framework to test whether this assessment holds an empirical evaluation. In this paper, a research design was developed with the goal of examining institutional changes that have been introduced by Fidesz. At the base of this was the concept of embedded democracy by Merkel et al. (2003), which was chosen due to its important analytical advantages over other definitions of liberal democracy: it allows a differentiated analysis due to its conceptual division of democracy into partial regimes. Moreover, Merkel et al. developed several indicators that are useful 
to empirical research on democracy. We adapted these indicators and included some more to examine the institutional changes in Hungary.

Based on this framework, five changes in the new Fundamental Law were examined in comparison to the old one as well as two articles of the Fundamental Law's Transitional Provisions. The empirical results were somehow unexpected if we consider the harsh criticism among the literature on the new constitution, as discussed in the second and fifth sections. This criticism led to the assumption that the new constitution blatantly violated basic principles of liberal democracy. While there are some changes that clearly weakens the democratic system, there are a few where this appreciation is not clear, at best.

According to our analysis, only one of the five constitutional changes examined revealed a clear breach of one of the sub-regimes of the Hungarian democracy (specifically, the provision that the HCC cannot rule over budgetary and fiscal matters when public debt is over 50\%). In addition, we consider one of the two articles of the examined transitional provisions, namely the new recognition method for religious communities, to be another violation of liberal democratic principles. The other transitional provision could also be considered as an attack to liberal principles, as our argumentation showed ${ }^{13}$. For these breaches, Hungary constitutes both an illiberal and delegative democracy, according to our approach.

On the other hand, the assessment of whether the creation of the Budget Council pushes Hungary from a liberal to an "illiberal" democracy is rather unclear. Subsequently, in two cases in which concerns have been expressed in the literature, no breach of the liberal requirements of democracy can be observed ${ }^{14}$. Finally, even though the new election method of the HCC justices follows a standard procedure employed in most European countries, where the election of these justices is usually based on a two-thirds majority in the Parliament, we consider it important to emphasize that under the current political conditions (a stable two-thirds majority of the governing coalition), the new disposition may nevertheless lead to a constraint on the checks and balances system. The abolished method, where a consent between most parties was required, at least guaranteed a broader participation of political actors in the nomination of the HCC members.

This last consideration makes it clear that the real threat to liberal democracy in Hungary comes less (or not solely) from constitutional or other legal norms, but from the application of these norms under the current political conditions. Viewed this way, the studied reforms add up to a situation where the power of the ruling party increases as the democratic counterweights weaken. In fact, as illustrated by the creation of the Budget Council, Fidesz has used its supermajority to ensure that it can still influence fiscal policy in the future. In this sense, tit is the coalescence of seemingly harmless laws and the stable two-thirds majority that Fidesz enjoys what

\footnotetext{
13 The creation of the National Office for the Judiciary limits the self-administration of the Judiciary. The election of this new organ's President is also worrisome, since it can be regarded as a political institution (the Parliament) unnecessarily exerting influence over the judiciary.

14 We seriously doubt that the new appointment method of the HCC President and the abolishment of the right of every citizen to appeal to the Court for every matter can be considered violations of liberal democratic principles.
} 
constitutes the most important threat for the principles that underpinned Hungarian democracy. In particular, the factual cementing of the parliamentary majority of Fidesz and its coalition partner KDNP through the reform of the electoral law as well as the dominance of Fidesz in the media sector leads to the conclusion that especially the principle of the separation of powers is violated in practice even more clearly than the results of this study suggest.

Our second research question concerned the possible link between the documented violations of liberal democracy and the populist character of the ruling party. We expected that government activities aimed at achieving institutional changes on the basis of the populist ideology would be found mainly in the area of separation of powers and civil rights. We assumed that the government would want to weaken institutional checks and balances in order to give unrestricted recognition to the will of the people, which - in its view-it alone represents. At the same time, we assumed that further changes would be aimed at restricting the rights of ethnic and social minorities, since populist parties are convinced that the people is homogenous, and that special protection of minorities is therefore not justified.

In fact, it is clear to us that the restriction of the HCC's review right in budgetrelated areas (Article 37 IV of the Basic Law) represents a desire to restrict the control options of another constitutional body in favor of the "popular will", which is ultimately channeled by the parliamentary majority and the government. In the same vein, it could be assumed that rising the hurdles for the recognition of religious communities (Article 21 of the transitional provisions) accounts for an intention to hinder certain minorities from obtaining a legal status that would increase their protection before the law.

The creation of the Budget Council, which we did not clearly classify as an "illiberal" measure, is paradoxical since it represents a widening of checks and balances. However, it can be assumed that this new institution is not employed to strength the institutional counterweights, since the members of this body are in any case directly or indirectly chosen by the parliamentary majority. Due to the long period of time in office, it could be used in the future to ensure that the political will of Fidesz still have a decisive influence on the policy of a new government, if Fidesz was ever to lose a future election.

Unfortunately, our study had two main limitations. The first one is the language barrier to explore these changes. To solve this, secondary literature highlighting the new characteristics of the Fundamental Law was employed. The second limitation is the small sample size. We have analyzed merely seven institutional changes in a government known for introducing new reforms constantly. Therefore, caution must be taken when generalizing these results.

Despite these limitations, our approach could be applied to explore more institutional changes in liberal democracies generally, and in Hungary particularly. Further work needs to be done to establish whether other institutional changes, such as the new Media Law, can be regarded as breaches of liberal principles. Through this way, not only democratic regressions but also institutional developments in young democracies can be asserted. 


\section{Appendix A}

The embedded democracy's basic conditions, or criteria by Merkel et al. (2003)

1. Vertical Dimension

a. Electoral Regime

I. Right to active suffrage

II. Right to stand for election

III. Free and fair elections

IV. Elected officials

b. Political Rights Regime

I. Freedom of opinion, press and information

II. Freedom of association

2. Horizontal Dimension

a. Civil Rights

I. Protection of individual rights against state and private actors

II. Equal treatment by and equal access to courts

b. Division of Power and Horizontal Accountability

I. Separation of power's principle

3. Transversal Dimension, or Agenda Control Dimension

a. Effective government

I. Elected officials with real power

Source: Merkel et al. (2003, p. 57).

\section{Appendix B}

Indicators to evaluate institutional changes based on the embedded democracy's criteria

\section{Electoral regime}

I. Right to active suffrage

A. Indicator: Exclusion

1. Does the institutional change exclude legally a segment of the population from the right to vote? ${ }^{15}$

2. Does the institutional change exclude factually a segment of the population from the right to vote? ${ }^{16}$

II. Right to stand for election

B. Indicator: Exclusion

15 For instance, exclusion due to race, sex or economic position within the society.

16 By factually, we refer to exclusion that is not typified in any law. For instance, exclusion due to repression or severe poverty. Merkel et al. trace back this type of exclusion to physical or structural violence (Merkel et al. 2003, p. 80). Subsequently, for the second criterion apply the same reflections. 
3. Does the institutional change exclude legally a segment of the population from the right to stand for election?

4. Does the institutional change exclude factually a segment of the population from the right to stand for election?

III. Free and fair elections

C. Indicator: Competitive and open elections

5. Does the institutional change prohibit or facilitate the prohibition of political parties? ${ }^{17}$

6. Does the institutional change hinder the competition against the ruling party ${ }^{18}$

7. Does the institutional change reduce the number of elections?

D. Indicator: Proper Election Process

8. Does the institutional change facilitate elections' manipulation? ${ }^{19}$

9. Does the institutional change decrease the impartiality of the electoral authority? ${ }^{20}$

10. Does the institutional change decrease the enforcement power of the electoral authority?

IV. Elected officials

E. Indicator: Number of elected officials

11. Does the institutional change decrease the number of constitutionally elected rulers?

F. Indicator: Designation source of non-democratically elected officials

12. Does the institutional change increase the number of authorities without democratic legitimation?

13. Does the institutional change provide non-democratically elected officials with competencies that are not usually part of their area? ${ }^{21}$

\section{Political rights}

V. Freedom of opinion and press

G. Indicator: Legal regulations

\footnotetext{
17 By facilitate, we refer extending the range of reasons why a party may be banned. For instance, by including in the electoral law an article that increases the number of members that a party must have to exist or participate in elections.

${ }^{18}$ By this, we refer to changes that directly favor the ruling party; for instance, granting all the economic support of the state to the party with most votes.

19 By this, we mean whether it is easier to buy votes, to change electoral lists or to change electoral rolls.

${ }^{20}$ By this, we mean whether the institutional change increases the formal or informal dependence of the members of the electoral authority to state organs. Formal dependence means whether the executive can now choose or dismiss the electoral authorities. Informal dependence refers to any form of political influence that does not concern the formal election process of the electoral authority. For instance, the economic dependence to decisions of the executive.

${ }^{21}$ As already explained in Chap. 3.2.5, here applies the differentiation between democratic delegation of power and the competencies gained in a transition. This question refers to the latter.
} 
14. Does the institutional change prohibit or hinder the foundation of organizations that make freedom of expression possible?22

15. Does the institutional change hinder the journalistic work? ${ }^{23}$

H. Indicator: Economic independence

16. Does the institutional change increment the communication media's economic dependence on the state ${ }^{24}$

17. Does the institutional change increment or authorize penalties to the communication media?

VI. Freedom of association

I. Indicator: Political associations

18. Does the institutional change prohibit or facilitate the prohibition of political parties? ${ }^{25}$

19. Does the institutional change hinder the creation or operation of political parties? ${ }^{26}$

20. Does the institutional change increase the requirements to form a political party?

J. Indicator: Citizens' associations

21. Does the institutional change prohibit any form of civil organizations?

22. Does the institutional change hinder the creation or operation of citizens associations?

23. Does the institutional change increase the requirements to form a citizens' association?

K. Indicator: Right to demonstrate

24. Does the institutional change prohibit civil protest?

25 . Does the institutional change hinder civil demonstrations $?^{27}$

\section{Civil rights}

VII. Protection of individual rights against state and private actors

L. Indicator: Legal regulations

26. Does the institutional change decrease the legal protection against state interference in the private life?

27. Does the institutional change decrease the legal protection against private actors' interventions in the private life?

\footnotetext{
22 These organizations constitute all sort of means to communicate ideas, critiques, opinions, etc.

23 By this, we refer to legal regulations that can be an obstacle to journalistic work. For instance, the introduction of new permits that the journalists need to have before reporting news on politics.

24 For instance, whether the institutional change foresees that the only funding source of newspapers can be the state.

25 Since it influences both regimes, this question needs to be in this list twice. Here apply the same guidelines as footnote 8 .

26 For instance, by introducing new regulations such as a minimum number of members or money that the party needs to have. For the second indicator apply the same guidelines.

27 By this, we refer to legal regulations that are not typified in the constitution and can be an obstacle to pacific demonstrations. For instance, the introduction of new permits that need to be granted.
} 
28. Does the institutional change decrease the number of people that are protected against private or state interventions?

M. Non-Legal regulations

29. Does the institutional change decrease the protection of minorities? ${ }^{28}$

VIII.Equal treatment by and equal access to courts

N. Indicator: Equal access to courts

30. Does the institutional change decrease the number of people that can access to a court?

31. Does the institutional change make more difficult the access to courts ${ }^{29}$

O. Indicator: Equal treatment by courts

32. Does the institutional change foresee that the courts provide different treatment, directly or indirectly, to different segments of populations ? $^{30}$

\section{Division of power and horizontal accountability}

IX. Separation of power's principle

P. Indicator: Separation of Powers

33. Does the institutional change increment the competencies of one organ at the expenses of another?

34. Does the institutional change decrease the control options of the judiciary towards the other branches of power?

35. Does the institutional change decrease the control options of the Parliament towards the executive power?

36 Does the institutional change decrease the independence of judicial courts? $?^{31}$

37. Does the institutional change decrease the enforcement power of the judicial courts?

38. Does the institutional change decrease the number of areas over which the judiciary can rule?

\section{Effective power to govern}

X. Elected officials with real power

Q. Indicator: Institutional Veto-Power of non-democratically elected officials ${ }^{32}$

\footnotetext{
${ }^{28}$ Cultural, religious and linguistic characteristics of minorities must be protected by the state (Merkel et al. 2003, p. 85).

29 For instance, the mentioned change can facilitate the attendance to courts of certain segments of population, that before could not assist to a court due to geographic or economic reasons.

30 Due to social status or conditions concerning minorities, for example.

31 This means whether the institutional change grants the executive or legislative power competencies to influence the proper functioning of judicial courts. For instance, this happens if the executive can now choose the members of the courts. The institutional change can act subtly: For example, by defining that the founding source of the judicial organs is now the legislative. This question refers to all types of possible influences that the legislative or executive can have over judicial courts and did not have before.

32 The same guidelines of the Chap. 3.1.2 apply here. Because of the difficulty of defining proper standards for this section, Merkel et al. recommend a differentiate analysis for each case (Merkel et al. 2003, p. 95).
} 
39. Does the institutional change assign functions of democratically elected rulers to non-democratically elected officials?

40 Does the institutional change increment the functions of non-democratically elected rulers in areas usually reserved to democratically elected rulers?

41. Does the institutional change reduce the competencies of democratically elected officials for the benefit of non-democratically elected officials in areas usually reserved to democratically elected rulers?

42. Does the institutional change decrease the control options of democratically elected rulers over non-democratically elected officials?

Source: Adaptation of Merkel et al. (2003, pp. 73-95) and Bertelsmann Stiftung (2018).

Funding Open Access funding enabled and organized by Projekt DEAL.

Open Access This article is licensed under a Creative Commons Attribution 4.0 International License, which permits use, sharing, adaptation, distribution and reproduction in any medium or format, as long as you give appropriate credit to the original author(s) and the source, provide a link to the Creative Commons licence, and indicate if changes were made. The images or other third party material in this article are included in the article's Creative Commons licence, unless indicated otherwise in a credit line to the material. If material is not included in the article's Creative Commons licence and your intended use is not permitted by statutory regulation or exceeds the permitted use, you will need to obtain permission directly from the copyright holder. To view a copy of this licence, visit http://creativecommons.org/licenses/by/4. $0 \%$

\section{References}

Ádám, Zoltán, and András Bozóki. 2016. State and Faith: Right-wing Populism and Nationalized Religion in Hungary. Intersections 2:98-122.

Ágh, Attila. 2013. The Triple Crisis in Hungary: The "Backsliding" of Hungarian Democracy after Twenty Years. Romanian Journal of Political Science 13:25-51.

Ágh, Attila, Jürgen Dieringer, and Frank Bönker. 2020. Hungary Report: Sustainable Governance Indicators. Gütersloh: Bertelsmann Stiftung.

Akkerman, Tjitske. 2017. Populist Parties in Power and Their Impact on Liberal Democracies in Western Europe. In Political Populism: A Handbook, ed. Reinhard Heinisch, Christina Holtz-Bacha, and Oscar Mazzoleni, 169-180. Baden-Baden: Nomos.

Albertazzi, Daniele, and Sean Mueller. 2013. Populism and liberal democracy: Populists in government in Austria, Italy, Poland and Switzerland. Government and Opposition 48:343-371.

Bajomi-Lázár, Péter. 2015. Party Colonization of the Media: The Case of Hungary. In The Hungarian Patient: Social Opposition to an Illiberal Democracy, ed. P. Krasztev, J.V. Til, 50-80. Budapest, New York: Central European University Press.

Benveniste, Annie, Giovanna Campani, and Gabriella Lazaridis. 2016. The Rise of the Far Right in Europe: Populist Shifts and 'Othering'. London: Palgrave Macmillan.

Bergmann, Eirikur. 2020. Neo-Nationalism. The Rise of Nativist Populism. Berlin: Springer.

Bertelsmann Stiftung. 2018. Codebook for Country Assessments of the Transformation Index

Biró-Nagy, András. 2017. Illiberal Democracy in Hungary: The Social Background and Practical Steps of Building an Illiberal State. Colección Monografías CIDOB 2017:31-44.

Bogaards, Matthijs. 2018. De-democratization in Hungary: Diffusely Defective Democracy. Democratization 25:1481-1499.

Bozóki, András. 2015. Broken Democracy, Predatory State and Nationalist Populism. In The Hungarian Patient: Social Opposition to an Illiberal Democracy, ed. P. Krasztev, J.V. Til, 3-36. Budapest, New York: Central European University Press. 
Bugaric, Bojan. 2014. Protecting Democracy and the Rule of Law in the European Union: The Hungarian Challenge. LEQS Paper No. 79/2014. London School of Economics "Europe in Question".

Buzogány, Aran. 2017. Illiberal Democracy in Hungary: Authoritarian Diffusion or Domestic Causation? Democratization 24:1307-1325.

Bánkuti, Miklós, Gábor Halmai, and Kim Scheppele. 2012. From Separation of Powers to a Government without Checks: Hungary's Old and New Constitutions. In Constitution for a Disunited Nation: On Hungary's 2011 Fundamental Law, ed. Gábor Tóth, 237-268. Budapest, New York: Central European University Press.

Bánkuti, Miklós, Gábor Halmai, and Kim Scheppele. 2015. Hungary's Illiberal Turn: Disabling the Constitution. In The Hungarian Patient: Social Opposition to an Illiberal Democracy, ed. P. Krasztev, J.V. Til, 37-46. Budapest, New York: Central European University Press.

Canovan, Margaret. 1999. Trust the People: Populism and the Two Faces of Democracy. Political Studies 47:2-16.

De la Torre, Carlos. 2000. Populist Seduction In Latin America: The Ecuadorian Experience. Athens: Ohio University Press.

Freedom House. 2019. Freedom in the World 2019: Democracy in Retreat. https://freedomhouse.org/sites/ default/files/Feb2019_FH_FITW_2019_Report_ForWeb-compressed.pdf. Accessed 30 June 2021.

Fundamental Law of Hungary. 2011. Translation of the Ministry of Justice

Galston, William. 2018. The Populist Challenge to Liberal Democracy. Journal of Democracy 29:5-19.

de Ghantuz Cubbe, Giovanni. 2021. Populistische Parteien und Verfassungsgerichte. Zu den Spezifika eines grundlegenden Spannungsverhältnisses. Recht und Politik. Zeitschrift Für deutsche und Europäische Rechtspolitik 5:110-119. Beiheft.

Gómez, Gabriel. 2020. Fidesz, Liberal Democracy and the Fundamental Law in Hungary. Unpublished Bachelor Thesis (It can be sent upon request). Friedrich-Schiller-University of Jena.

Halmai, Gábor. 2018. Is There Such Thing as 'Populist Constitutionalism'? The Case of Hungary. Fudan Journal of the Humanities and Social Sciences 11:323-339.

Hegedüs, Daniel. 2018. Rethinking the Incumbency Effect. Radicalization of Governing Populist Parties in East-Central-Europe. A Case Study of Hungary. CGP Working Paper Series, Vol. 09/2018, 32-57.

Huber, Robert A., and Christian H. Schimpf (2017) On the Distinct Effects of Left-Wing and Right-Wing Populism on Democratic Quality. Politics and Governance 5(4):146-165. https://doi.org/10.17645/ pag.v5i4.919.

Huber, Robert A., and Christian H. Schimpf. 2018. Populism and Democracy-Theoretical and Empirical Considerations. In Political Populism: A Handbook, ed. Reinhard Heinisch, Christina Holtz-Bacha, and Oscar Mazzoleni, 329-344. Baden-Baden: Nomos.

Jakab, András, and Pál Sonnevend. 2013. Continuity with Deficiencies: The New Basic Law of Hungary. European Constitutional Law Review 9:102-138.

Kaltwasser, Cristóbal. 2012. The Ambivalence of Populism: Threat and Corrective for Democracy. Democratization 19:184-208.

Kneip, Sascha. 2016. Verfassungsgerichte in der Vergleichenden Politikwissenschaft. In Handbuch Vergleichende Politikwissenschaft, ed. Hans-Joachim Lauth, Marianna Kneuer, and Gert Pickel, 361-372. Wiesbaden: Springer VS.

Kovács, Kriszta, and Gábor Tóth. 2011. Hungary's Constitutional Transformation. European Constitutional Law Review 7:183-203.

Kovács, Zoltán, and György Vida. 2015. Geography of the New Electoral System and Changing Voting Patterns in Hungary. Acta Geobalcanica 1:55-64.

Küpper, Herbert. 2012. Ungarns neues Grundgesetz von 2011. Kein Grund zum Jubel, aber auch noch nicht das Ende der Demokratie. Südosteuropa Mitteilungen 3:80-101.

Madrid, R.L. 2008. The Rise of Ethnopopulism in Latin America. World Politics 60:475-508.

Mahoney, James, and Thelen Kahtleen. 2010. Explaining Institutional Change: Ambiguity, Agency and Power. Cambridge: Cambridge University Press.

Mény, Yves, and Yves Surel. 2002. Democracies and the Populist Challenge. Basingtoke: Palgrave.

Merkel, Wolfgang. 2004. Embedded and Defective Democracies. Democratization 11:33-58.

Merkel, Wolfgang, Hans-Jürgen Puhle, Aurel Croissant, Claudia Eicher, and Peter Thiery. 2003. Defekte Demokratie: Band 1: Theorie. Opladen: Leske \& Budrich.

Mudde, Cas. 2004. The Populist Zeitgeist. Government and Opposition 39:542-563.

Mudde, Cas. 2007. Populist Radical Right Parties in Europe. New York: Cambridge University Press.

Mudde, Cas. 2016. Europe's Populist Surge: A Long Time in the Making. Foreign Affairs 95:25-30.

Mudde, Cas, and Cristóbal Kaltwasser. 2012. Populism in Europe and the Americas. Cambridge: Cambridge University Press. 
Mudde, Cas, and Cristóbal R. Kaltwasser. 2013. Exclusionary vs. Inclusionary Populism: Comparing Contemporary Europe and Latin America. Government and Opposition 48:147-174.

OECD. 2020. General Government Debt (Indicator). Accessed 21 Sept 2020. https://doi.org/10.1787/ a0528cc2-en.

Pappas, Takkis. 2014. Populist Democracies: Post-Authoritarian Greece and Post-Communist Hungary. Government and Opposition 49:1-23.

Pappas, Takkis. 2016. Distinguishing Liberal Democracy's Challengers. Journal of Democracy 27:22-36.

Plattner, Marc F. 2010. Populism, Pluralism and Liberal Democracy. Journal of Democracy 21:81-92.

Pogány, István. 2013. The Crisis of Democracy in East Central Europe: The 'New Constitutionalism' in Hungary. European Public Law 19:341-368.

Rummens, Stefan. 2017. Populism as a Threat to Liberal Democracy. In The Oxford Handbook of Populism, ed. Cristóbal Kaltwasser, Paul Taggart, Paulina Ochoa, and Pierre Ostiguy, 554-570. New York: Oxford University Press.

Rydliński, Bastosz. 2018. Viktor Orbán-First Among Illiberals? Hungarian and Polish Steps Towards Populist Democracy. Online Journal Modelling the New Europe 26:95-107.

Scheppele, Kim Lane. 2013. Not Your Father's Authoritarianism: The Creation of the "Frankenstate". In Newsletter of the European Politics and Society Section of the American Political Science Association, 5-9.

Scheppele, Kim Lane. 2014. Hungary, an Election in Question, Part 3: Compensating the Winners. The New York Times. Feb 28, 2014.

Schmidt, Andrea. 2018. Challenges of the Illiberal Democracy in Hungary: Some Aspects to the 2018 Elections. Polish Political Science Review 6:70-90.

Spittler, Marcus. 2018. Are Right-Wing Populist Parties a Threat to Democracy? In Democracy and Crisis-Challenges in Turbulent Times, ed. Wolfgang Merkel, Sascha Kneip, 97-121. Wiesbaden: Springer VS.

Uitz, Renata. 2012. Hungary's New Constitution and its New Law on Freedom of Religion and Churches: The Return of the Sovereign. Brigham Young University Law Review 3:931-968.

Van Kessel, Stijn. 2015. Populist Parties in Europe: Agents of Discontent? London: Palgrave Macmillan.

Vörös, Imre. 2015. Hungary's Constitutional Evolution During the Last 25 Years. Südosteuropa, Zeitschrift für Politik und Gesellschaft 63:173-200. 